\title{
The relation between deoxycytidine kinase activity and the radiosensitising effect of gemcitabine in eight different human tumour cell lines
}

\author{
Bea Pauwels*1, Annelies EC Korst ${ }^{1}$, Greet GO Pattyn ${ }^{1}$, Hilde AJ Lambrechts ${ }^{1}$, \\ Juliette AE Kamphuis ${ }^{2}$, Christel MJ De Pooter ${ }^{3}$, Godefridus J Peters², \\ Filip Lardon ${ }^{1}$ and Jan B Vermorken ${ }^{1}$
}

Address: ${ }^{1}$ Laboratory of Cancer Research and Clinical Oncology, Department of Medical Oncology, University of Antwerp (UA/UZA), Wilrijk, Belgium, ${ }^{2}$ Department Medical Oncology, VU University Medical Center, Amsterdam, The Netherlands and ${ }^{3}$ Department of Radiotherapy, St Augustinus Hospital, Wilrijk, Belgium

Email: Bea Pauwels* - bea.pauwels@ua.ac.be; Annelies EC Korst - Vinke@zeelandnet.nl; Greet GO Pattyn - greet.pattyn@ua.ac.be;

Hilde AJ Lambrechts - hilde.lambrechts@ua.ac.be; Juliette AE Kamphuis - jae.kamphuis@vumc.nl; Christel MJ De

Pooter - christel_de_pooter@gvagroup.com; Godefridus J Peters - GJ.Peters@vumc.nl; Filip Lardon - filip.lardon@ua.ac.be;

Jan B Vermorken - jan.b.vermorken@uza.be

* Corresponding author

Published: 30 May 2006

BMC Cancer 2006, 6:142 doi:10.1 |86/|47|-2407-6-142
Received: 26 January 2006

Accepted: 30 May 2006

This article is available from: http://www.biomedcentral.com/I47/-2407/6//42

(c) 2006 Pauwels et al; licensee BioMed Central Ltd.

This is an Open Access article distributed under the terms of the Creative Commons Attribution License (http://creativecommons.org/licenses/by/2.0), which permits unrestricted use, distribution, and reproduction in any medium, provided the original work is properly cited.

\begin{abstract}
Background: Gemcitabine ( $\mathrm{dFdC}$ ) is an active antitumour agent with radiosensitising properties, shown both in preclinical and clinical studies. In the present study, the relation between deoxycytidine kinase $(\mathrm{dCK})$ activity and the radiosensitising effect of gemcitabine was investigated in eight different human tumour cell lines.
\end{abstract}

Methods: Tumour cells were treated with dFdC (0-100 nM) for $24 \mathrm{~h}$ prior to radiotherapy (RT) $\left(\gamma-\mathrm{Co}^{60}, 0-6 \mathrm{~Gy}\right.$, room temperature). Cell survival was determined 7, 8, or 9 days after RT by the sulforhodamine $B$ test. dCK activity of the cells was determined by an enzyme activity assay.

Results: A clear concentration-dependent radiosensitising effect of dFdC was observed in all cell lines. The degree of radiosensitisation was also cell line dependent and seemed to correlate with the sensitivity of the cell line to the cytotoxic effect of dFdC. The dCK activity of our cell lines varied considerably and differed up to three fold from 5 to $15 \mathrm{pmol} / \mathrm{h} / \mathrm{mg}$ protein between the tested cell lines. In this range $\mathrm{dCK}$ activity was only weakly related to radiosensitisation (correlation coefficient $0.62, p=0.11$ ).

Conclusion: Gemcitabine needs to be metabolised to the active nucleotide in order to radiosensitise the cells. Since dFdCTP accumulation and incorporation into DNA are concentration dependent, the degree of radiosensitisation seems to be related to the extent of dFdCTP incorporated into DNA required to inhibit DNA repair. The activity of $\mathrm{dCK}$ does not seem to be the most important factor, but is clearly a major factor. Other partners of the intracellular metabolism of gemcitabine in relation to the cell cycle effects and DNA repair could be more responsible for the radiosensitising effect than $\mathrm{dCK}$ activity. 


\section{Background}

Gemcitabine (2',2'-difluorodeoxycytidine, dFdC) is a synthetic pyrimidine nucleoside analogue that has a structure very similar to that of deoxycytidine and cytosine arabinoside (Ara-C) [1]. In clinical use, gemcitabine is active against a variety of solid tumours such as cancers of the pancreas, lung, head and neck, bladder, breast, and ovary. It is activated intracellularly by deoxycytidine kinase $(\mathrm{dCK})$, which adds a phosphate group to the 5' position of the deoxyribose group. The diphosphate (dFdCDP) and triphosphate (dFdCTP) forms of the drug play an important role in the cytotoxic effect: $\mathrm{dFdCDP}$ is an inhibitor of ribonucleotide reductase, while $\mathrm{dFdCTP}$ is incorporated into DNA, both leading to the inhibition of DNA synthesis. At the same time, gemcitabine has several selfpotentiation mechanisms that serve to increase intracellular levels of the active metabolite and increase cytotoxicity $[1,2]$

In addition to its cytotoxic effect, gemcitabine is a potent radiosensitiser when used in rodent and human tumour cells, including pancreatic tumours, non-small cell lung cancer, head and neck cancer, colorectal, breast, ovarian and bladder cancer [3-14]. Gemcitabine can lead to a radiosensitising effect in both monolayer and spheroid glioblastoma cultures [15]. Recent in vivo studies have confirmed these observations and have shown significant tumour growth delay with the combination of gemcitabine and ionising radiation in animal models $[4,5,16]$. These results have prompted a variety of clinical trials using gemcitabine as a radiosensitiser [17-31]. The exact mechanism of radiosensitisation and most important factors are still not known yet. Although the effects of gemcitabine on cell cycle redistribution and deoxynucleotide triphosphate (dNTP) pools may contribute to, or even be necessary for, gemcitabine-mediated radiosensitisation $[7,10,13]$, they do not ultimately determine whether or not gemcitabine treatment is going to result in enhanced radiosensitivity. For example, the role of dATP depletion could not be confirmed in a study using cells with different repair defects [32]. Wachters et al [33] have shown that gemcitabine can sensitise cells to radiation by specific interference with the homologous repair (HR) pathway. Others have suggested that gemcitabine in combination with radiotherapy is compromised by mismatch repair (MMR), because recovery from gemcitabine treatment is facilitated by, although not dependent on MMR proficiency $[34,35]$

As a prodrug, gemcitabine requires intracellular phosphorylation to its active triphosphate form by dCK and to a lesser extent by thymidine kinase (TK2) [36] to exhibit biological activity. Acquired resistance to gemcitabine has been associated with deficiency of dCK [37-40] It has been shown that the expression of $\mathrm{dCK}$ at mRNA, protein and activity level in cancer cell lines of different origin were closely related and a correlation between the sensitivity to gemcitabine and the activity of dCK was observed [41]. It has also been shown that sensitivity to nucleoside analogues could be restored by transfection of a wild type $\mathrm{dCK}$ cDNA [42-44]. The critical role of dCK in gemcitabine's radiosensitisation is not known. Previously a significant relationship between dCK activity and sensitivity of various xenografts to gemcitabine was described [41] while accumulation of the triphosphate, dFdCTP, was related to sensitivity to gemcitabine also [45]. Earlier data with a gemcitabine resistant cell line, i.e. lacking $\mathrm{dCK}$, showed that these cells required a high concentration (50-100 $\mu \mathrm{M})$ of gemcitabine in order to get radiosensitisation [46]. However, because radiosensitisation in vitro increases with the drug concentration $[12,47])$., it could be that the radiosensitising effect of gemcitabine also depends on the rate of drug phosphorylation which in turn depends on dCK activity [8] and drug concentration $[12,13,37,45,48])$. Therefore, it has be hypothesized that dCK activity could be an important factor for the radiosensitising effect of gemcitabine.

The purpose of the present study was to further substantiate the role of dCK in gemcitabine's radiosensitisation. Most studies investigating the radiosensitising effect of gemcitabine are limited in cell types and only a few concentrations of gemcitabine are used. In this study, the radiosensitising effect of gemcitabine was investigated in eight human tumour cell lines, originating from different tissues, using a range of gemcitabine concentrations. Within that context, the role of dCK was further explored.

\section{Methods \\ Chemicals and reagents}

Dulbecco's Modified Eagle's Medium (DMEM), RPMI, Medium 199, fetal calf serum and the medium supplements L-glutamine and sodium pyruvate were all purchased from Invitrogen (Merelbeke, Belgium). Sulforhodamine B was obtained from ICN (Asse, Belgium). Gemcitabine was purchased from Eli Lilly (Indianapolis, USA).

\section{Cell lines}

The cell lines used in this study were human tumour cells differing in p53 status originating from different tissues: ECV304 (mt-p53) a human epidermoid bladder cancer cell line, H292 (wt-p53) a human mucoepidermoid lung cancer cell line, A549 (wt-p53) a human squamous lung cancer cell line, MCF-7 (wt-p53) a mammary carcinoma cell line, HT-29 (mt-p53) a colon adenocarcinoma cell line, Panc-1 (mt-p53) a human pancreatic epitheloid cell line, CAL-27 (mt-p53) a human squamous cell carcinoma cell line of the tongue and FaDu (mt-p53) a human squamous cell carcinoma cell line of the pharynx. H292 and 
A549 were cultured in RPMI-1640 medium, supplemented with glutamine, sodium pyruvate and $10 \%$ fetal calf serum. ECV304 was cultured in Medium-199 supplemented with $10 \%$ fetal calf serum. MCF-7, HT-29, CAL-27 and FaDu were cultured in DMEM medium, supplemented with glutamine and 10\% fetal calf serum. Cultures were maintained in exponential growth in a humidified atmosphere at $37^{\circ} \mathrm{C}$ under 5\% $\mathrm{CO}_{2} / 95 \%$ air.

\section{Cell survival after treatment with gemcitabine and radiation}

The sulforhodamine B (SRB) test is a suitable test system for in vitro radiosensitivity testing, which in the presently used cell lines has shown to be comparable in outcome with the clonogenic assay, when cells are allowed to undergo at least 6 doubling times after radiation treatment [49]. Therefore, in our experiments, ECV304, H292, A549, MCF-7, HT-29 and FaDu cells were incubated for 7 days, CAL-27 cells for 8 days and Panc- 1 cells for 9 days after radiation treatment, before determination of the survival by the SRB assay. Optimal seeding densities were determined for each cell line to assure exponential growth during the assay.

Cells were harvested from exponential phase cultures by trypsinisation, counted and plated in 48-well plates. Following plating and a $24 \mathrm{~h}$ recovery period, cells were treated with gemcitabine $(0-100 \mathrm{nM})$ dissolved in phosphate buffered saline (PBS) during $24 \mathrm{~h}$ immediately followed by radiation. PBS was added to control cells. Each concentration was tested six times within the same experiment. After irradiation at room temperature over a dose range of 0-6 Gy, using a ${ }^{60} \mathrm{Co}$ source (Alcyon, St Augustinus hospital, Antwerp), cells were washed with drug free medium. After 7,8 or 9 days, the survival was determined by the SRB assay. For determination of cell survival after treatment with gemcitabine alone, the SRB assay was performed 4 days after the start of treatment.

The SRB assay was performed according to the method of Skehan and colleagues and Papazisis and colleagues, with minor modifications $[50,51]$ Culture medium was aspirated prior to fixation of the cells by addition of $200 \mu \mathrm{l}$ $10 \%$ cold trichloroacetic acid. After $1 \mathrm{~h}$ incubation at $4{ }^{\circ} \mathrm{C}$, cells were washed 5 times with deionised water. Then the cells were stained with $200 \mu \mathrm{l} 0.1 \%$ SRB dissolved in 1\% acetic acid for at least 15 minutes and subsequently washed 4 times with $1 \%$ acetic acid to remove unbound stain. The plates were left to dry at room temperature and bound protein stain was solubilised with $200 \mu \mathrm{l} 10 \mathrm{mM}$ unbuffered TRIS base (tris(hydroxymethyl)aminomethane) and transferred to 96 wells plates for reading the optical density at $540 \mathrm{~nm}$ (Biorad 550 microplate reader, Nazareth, Belgium).

\section{dCK enzyme activity assays}

To determine a possible correlation between dCK activity and the radiosensitising effect of gemcitabine, cells were harvested as described previously [41], and pellets were stored at $-80^{\circ} \mathrm{C}$ until analysis. $25.10^{6}$ cells were used in order to be able to measure enzyme activity in a linear range for time and protein. dCK was determined essentially as described previously [41]. To measure dCK selectively and bypass TK2 mediated phosphorylation of deoxycytidine, we used radiolabeled chlorodeoxyadenosine $\left(\left[{ }^{3} \mathrm{H}\right] \mathrm{CdA}\right)$ as the substrate [52], which is not activated by TK2. Enzyme activities were expressed as nmol product per h per mg protein ( $\mathrm{nmol} / \mathrm{h} / \mathrm{mg}$ protein).

\section{Statistical methods}

The survivals were calculated by: mean optical density (OD) of treated cells/mean OD of control cells $\times 100 \%$. The radiation survival curves were fitted according to the linear-quadratic model: surviving fraction $=\exp (-\alpha D-$ $\left.\beta \mathrm{D}^{2}\right)$, using Winnonlin (Pharsight, USA).

The following parameters were calculated: ID50, the radiation dose causing 50\% growth inhibition and IC50, the concentration gemcitabine causing 50\% growth inhibition. The radiosensitising effect was represented by the dose enhancement factor (DEF): ID50(-dFdC)/ ID50 $(+\mathrm{dFdC})$.

Unless otherwise indicated, all data are presented as the mean \pm standard deviation. All experiments were performed at least three times. A two-sample t-test and oneway ANOVA analysis was used to determine significance between ID50 values and DEFs.

Radiosensitisation can be defined as a synergistic interaction between gemcitabine and radiation. For the determination of synergism, the combination index (CI) was calculated by the Chou-Talalay equation $[47,53,54]$, using CalcuSyn (Biosoft, USA, UK). The general equation for the classic isobologram is given by:

$\mathrm{CI}=\frac{(\mathrm{D})_{1}}{\left(\mathrm{D}_{\mathrm{x}}\right)_{1}}+\frac{(\mathrm{D})_{2}}{\left(\mathrm{D}_{\mathrm{x}}\right)_{2}}$

where $\left(D_{x}\right)_{1}$ and $\left(D_{x}\right)_{2}$ in the denominators are the doses (or concentrations) for $\mathrm{D}_{1}$ (gemcitabine) and $\mathrm{D}_{2}$ (radiation) alone that give $\mathrm{x} \%$ inhibition, whereas $(\mathrm{D})_{1}$ and (D) ${ }_{2}$ in the nominators are the doses of gemcitabine and radiation in combination that also inhibit $\mathrm{x} \%$ (i.e., isoeffect).

The $\left(D_{x}\right)_{1}$ or $\left(D_{x}\right)_{2}$ (for gemcitabine and radiation) can be readily calculated from the median-effect equation of Chou: 
$D_{x}=D_{m}\left(\frac{f_{a}}{\left(1-f_{a}\right)}\right)^{1 / m}$

Where $f_{a}$ is the fraction affected and $D_{m}$ is the medianeffect dose (ID50 or IC50) that is obtained from the anti$\log$ of the X-intercept of the median effect plot, X-log (D)

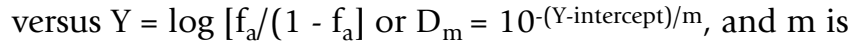
the slope of the median effect plot.

For conservative mutually nonexclusive isobolograms of two agents, a third term,

$$
\alpha \frac{(\mathrm{D})_{1}(\mathrm{D})_{2}}{\left(\mathrm{D}_{\mathrm{x}}\right)_{1}\left(\mathrm{D}_{\mathrm{x}}\right)_{2}}
$$

is added. The third term is usually omitted, when the mutually exclusive $(\alpha=0)$ assumption or classic isobologram is used $[53,55]$ Data in table 2 are based on the assumption that $\alpha=0$.

A CI value between 0.9 and 1.1 indicates only additivity. Moderate synergism is depicted by CI values between 0.7 and 0.9 , synergism by CI values below 0.7 .

\section{Results}

\section{Radiosensitisation by gemcitabine}

A clear concentration-dependent radiosensitising effect of gemcitabine was observed in ECV304, FaDu, H292, A549, CAL-27, Panc-1, MCF-7 and HT-29 cells (Figure 1 and 2). ID50 values and DEFs for the different gemcitabine concentrations are summarised in Table 1.

The degree of radiosensitisation seemed to be cell line dependent. For ECV304 and MCF-7 cells, the DEF after treatment with $1 \mathrm{nM}$ gemcitabine was 1.37 , and 1.24, respectively, while this concentration had no radiosensitising effect in FaDu, H292, A549, CAL-27 and HT-29 cells with DEF values around 1. In Panc-1 cells, much higher concentrations (15-100 $\mathrm{nM})$ of gemcitabine were required to obtain a radiosensitising effect than in the other cell lines (2-8 nM). Panc-1 cells were less sensitive for the cytotoxic effect of gemcitabine alone as depicted by the IC50 values in Table 1 . The radiosensitising effect seemed to correlate with the sensitivity of the cell line to the cytotoxicity effects of gemcitabine (correlation coefficient for mean IC50 and mean DEF: -0.82, p = 0.013).

The CI analysis showed that after treatment during $24 \mathrm{~h}$ with gemcitabine immediately before radiation treatment, there is synergism in ECV304 with gemcitabine concentrations of $2 \mathrm{nM}$ or higher $(\mathrm{CI} \leq 0.65)$, with concentrations of $4 \mathrm{nM}$ or higher in $\mathrm{A} 549(\mathrm{CI} \leq 0.70)$, MCF-7 $(\mathrm{CI} \leq 0.62)$ and $\mathrm{FaDu}(\mathrm{CI} \leq 0.50)$ and with concentrations of $6 \mathrm{nM}$ and higher in HT-29 cells $(\mathrm{CI} \leq 0.39)$. Only moderate synergism was observed with $6 \mathrm{nM}$ or higher in $\mathrm{H} 292(\mathrm{CI} \leq 0.88)$ and CAL-27 ( $\mathrm{CI} \leq 0.72)$. In Panc-1 cells, concentrations of $7 \mathrm{nM}$ and higher resulted in a moderate to synergistic interaction $(\mathrm{CI} \leq 0.79)$ (Figure 3$)$.

\section{dCK}

Since our cell lines had a normal sensitivity range (nM range) and had a DEF comparable to high and low values in literature, we measured dCK activity in order to determine whether there would be relation between DEF and dCK activity. Table 2 represents the dCK activity per cell line. The dCK activity varied considerably from cell line to cell line and differed up to three fold from 5 to $15 \mathrm{pmol} /$ $\mathrm{h} / \mathrm{mg}$ protein between the tested cell lines. In this range dCK activity was weakly related to DEF (correlation coefficient $=0.62, \mathrm{p}=0.11$ ) (Figure 4).

\section{Discussion}

This is the first study showing a clear concentrationdependent radiosensitising effect of gemcitabine in a large number of tumour cell lines, originating from different tissues. In addition, we found that that there was a weak positive correlation between dCK activity of these cells and the DEF. Probably, more factors, including other partners of the intracellular metabolism, cell cycle effects and DNA repair play a role. This offers an explanation for the variable results in the clinic.

In particular, we investigated the radiosensitising effect in 8 different cell lines, using various concentrations of gemcitabine. Our data demonstrate that gemcitabine increases the radiosensitivity of ECV304, H292, A549, MCF-7, HT29, CAL-27, Panc-1 and FaDu cells in vitro when the cells are treated for $24 \mathrm{~h}$ immediately before radiation. The enhancement is concentration dependent, with an increasing DEF with higher concentrations of gemcitabine.

Our DEFs are comparable to literature data from other cell lines $[6-13,46])$. In most of these studies, the concentration of gemcitabine needed to achieve such a radiosensitising effect, was higher than in our study. This seems to be dependent on the sensitivity to the single agent gemcitabine of the cell lines studied since in gemcitabine-resistant cell lines even $\mu \mathrm{M}$ concentrations of gemcitabine were required [46]. In addition, this could also be due to differences in DNA repair between the cells. In our experiments, the radiosensitising effect was cell line dependent; for example, higher gemcitabine concentrations were needed to induce radiosensitisation in Panc-1 cells (Table 1).

As mentioned gemcitabine is a prodrug that requires successive intracellular phosphorylations into its active trisphosphate form [56]. The enzyme $\mathrm{dCK}$ is required for the 
Table I: IC50, ID50 and DEFs of the different cell lines. Sensitivity of different cell lines for gemcitabine (indicated by IC50 values) and radiotherapy (indicated by ID50 values) alone and the radiosensitising effect of gemcitabine represented by dose enhancement factors (DEF). (mean \pm S.D.).

\begin{tabular}{|c|c|c|c|c|c|c|c|}
\hline Cell line & IC50 (nM) & ID50 (Gy) & DEF I nM & DEF 2 nM & DEF 4 nM & DEF 6 nM & DEF 8 nM \\
\hline ECV304 & $3.05 \pm 0.49$ & $3.37 \pm 0.40$ & $1.37 \pm 0.06$ & $2.4 I \pm 0.24$ & $3.21 \pm 0.25$ & $3.64 \pm 0.40$ & n.a. \\
\hline $\mathrm{FaDu}$ & $4.90 \pm 0.46$ & $3.09 \pm 0.39$ & $1.03 \pm 0.04$ & $1.22 \pm 0.17$ & $1.80 \pm 0.26$ & $2.37 \pm 0.52$ & n.a. \\
\hline $\mathrm{H} 292$ & $7.99 \pm 0.77$ & $4.00 \pm 0.86$ & $1.08 \pm 0.10$ & $1.23 \pm 0.20$ & $1.58 \pm 0.22$ & $2.07 \pm 0.55$ & $2.46 \pm 0.82$ \\
\hline A549 & $9.01 \pm 0.89$ & $4.51 \pm 0.70$ & $1.00 \pm 0.04$ & $1.21 \pm 0.17$ & $1.89 \pm 0.51$ & $2.39 \pm 0.57$ & $2.77 \pm 0.26$ \\
\hline CAL-27 & $8.92 \pm 1.59$ & $3.52 \pm 0.88$ & $1.06 \pm 0.07$ & $1.08 \pm 0.04$ & $1.49 \pm 0.21$ & $2.06 \pm 0.06$ & $2.5 \mathrm{I} \pm 0.2 \mathrm{I}$ \\
\hline MCF-7 & $6.94 \pm 2.03$ & $4.96 \pm 1.27$ & $1.24 \pm 0.06$ & $1.45 \pm 0.27$ & $1.63 \pm 0.13$ & $2.55 \pm 0.34$ & n.a. \\
\hline HT-29 & $7.75 \pm 1.61$ & $5.64 \pm 1.02$ & $1.12 \pm 0.21$ & $1.30 \pm 0.10$ & $1.62 \pm 0.04$ & $2.39 \pm 0.21$ & n.a. \\
\hline Cell line & IC50 (nM) & ID50 (Gy) & DEF $7 \mathrm{nM}$ & DEF I $5 \mathrm{nM}$ & DEF $35 \mathrm{nM}$ & DEF $50 \mathrm{nM}$ & DEF $100 \mathrm{nM}$ \\
\hline Panc-I & $77.8 \pm 9.1$ & $2.92 \pm 0.35$ & $1.20 \pm 0.10$ & $1.50 \pm 0.19$ & $1.55 \pm 0.19$ & $1.83 \pm 0.20$ & $1.56 \pm 0.08$ \\
\hline
\end{tabular}

n.a. not analysed

first phosphorylation step into dFdCMP, while non-specific kinases are responsible for the further phosphorylation steps. As it has been reported that the level of enzymatic activity of dCK could have a profound influence on cellular resistance to gemcitabine cytotoxicity, the present investigations were also designed to address the relationship between gemcitabine's radiosensitisation and the activity of dCK in various human tumour cell lines. The range of dCK activity found in our cell lines, is in agreement with the range found in other solid tumour cell lines, but lower than in leukemic cell lines [57]. For those cell lines investigated the extent of overall gemcitabine phosphorylation to dFdCTP is related to the drug concentration and the activity of $\mathrm{dCK}[37,45,57]$. However other enzymes also contribute to the overall accumulation and particularly the retention of dFdCTP, such as deoxycytidine deaminase, pyrimidine 5'nucleotidase (5'NT), aspecific nucleotidases and phosphatases, and incorporation into DNA and RNA.

Our results in 8 different human solid tumour cell lines with a varying radiosensitising effect of gemcitabine did not further validate the correlation between dCK activity of the cells and the radiosensitising effect of gemcitabine.
Gregoire et al [58] reported a correlation between dCK activity and gemcitabine's radiosensitisation. This correlation held both for dCK mRNA expression and the protein versus radiosensitisation [58]. Contrary to this, we could only show a weak relation between the DEF and $\mathrm{dCK}$ activity of eight different tumour cells. Possibly the range of dCK activity in our panel was not large enough. In the xenografts investigated for a relation between dCK activity and gemcitabine's antitumor activity was larger [41].

Several hypotheses have been proposed to explain the radiosensitisation potential of gemcitabine [59]. Of these, most likely, cell cycle synchronization $[7,60,61]$ and DNA repair [32] play an important role in the radiosensitisation. In addition to the intracellular metabolism of gemcitabine, for which dCK is a key factor, intrinsic variation in the cellular response to the analogue after ionising radiation is likely to also play a role in gemcitabine's radiosensitisation. The relative importance of dCK activity among these various parameters is, however, not clear. Possibly the overall rate of initial gemcitabine phosphorylation is also determined by the equilibrium between the activities of $\mathrm{dCK}$ and the degrading enzyme, $5^{\prime} \mathrm{NT}$, since the ratio $\mathrm{dCK} / 5^{\prime} \mathrm{NT}$ showed a better correlation with gemcitabine

Table 2: Deoxycytidine kinase (dCK) activity per cell line.

\begin{tabular}{lc}
\hline Cell line & dCK activity (nmol/h/mg protein) \\
\hline ECV304 & 15.29 \\
FaDu & 8.12 \\
H292 & 10.51 \\
A549 & 6.02 \\
CAL-27 & 5.02 \\
MCF-7 & 8.72 \\
HT-29 & 7.11 \\
Panc-I & 8.89
\end{tabular}



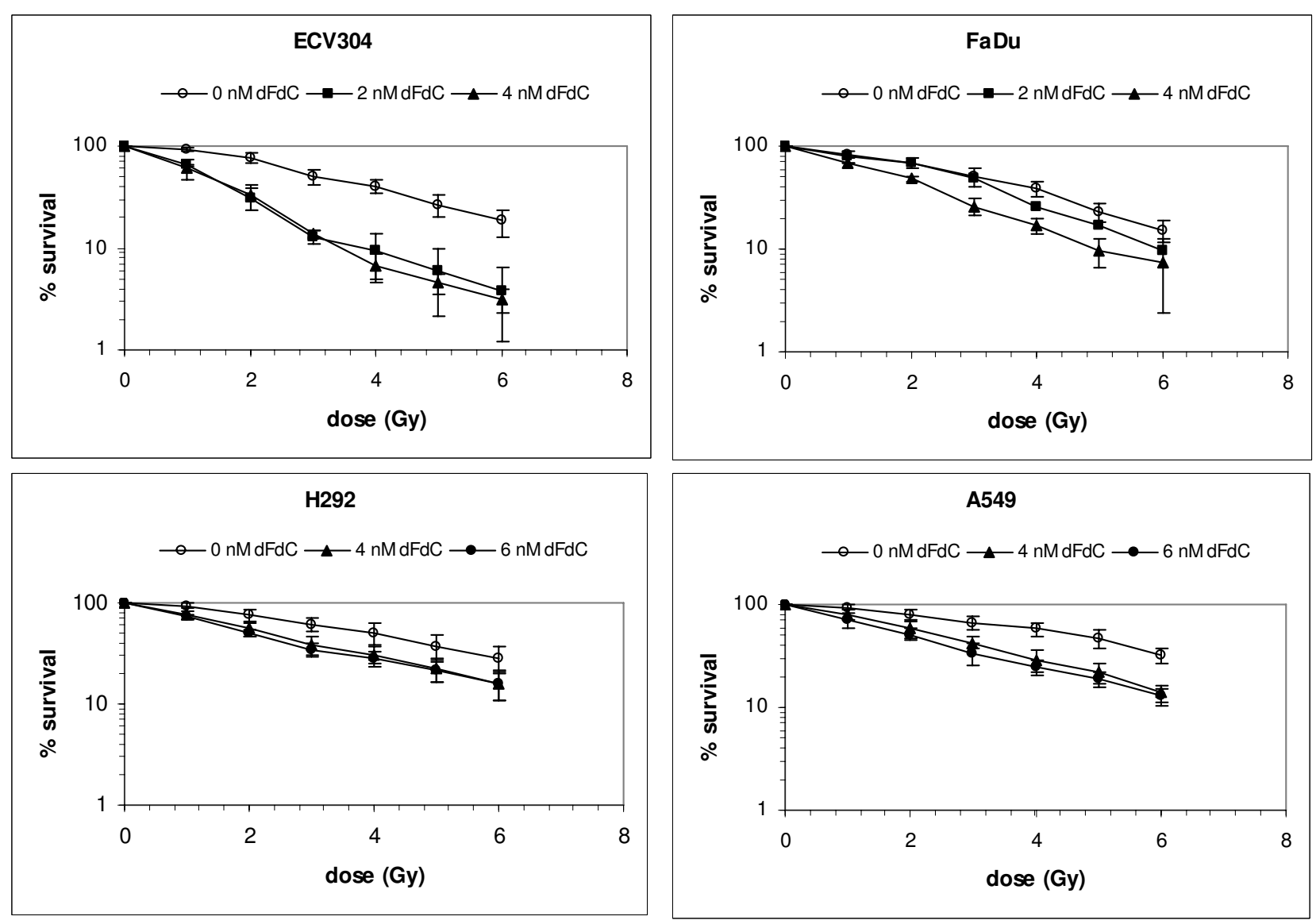

\section{Figure I}

Radiation dose response curves. Radiation dose responsecurves of ECV304, H292, A549, and FaDu cells after treatment with gemcitabine $(\mathrm{dFdC})$ during $24 \mathrm{~h}$ immediately before radiation $(\mathrm{RT})$ (survival \pm S.D.)

sensitivity than dCK activity alone [62]. Moreover, the final mode of action of gemcitabine of producing a "masked chain termination" after its incorporation into DNA, favours that DNA repair plays an important role with respect to sensitising the tumour cells to radiation.

\section{Conclusion}

Our study suggest that other partners of the intracellular metabolism of gemcitabine in relation to cell cycle effects and DNA repair could be more responsible for the radiosensitising effect of gemcitabine than dCK activity of the cell.

\section{Competing interests}

We have received financial support for doing studies with gemcitabine. Eli Lilly Company is not financing this manuscript.

\section{Authors' contributions}

BP participated in the design of the study, performed cell survival experiments, statistic analysis and drafted the manuscript; AEK, participated in the study design and coordination; GGP and HJL participated in the cell survival experiments and performed cell culture; JAK carried out the dCK activity measurement; CDP was involved in the irradiation experiments; GJP has made substantial contribution to the analysis and interpretation of the data and has been revising the manuscript critically; FL participated in the study design and coordination, helped to draft the manuscript and has been revising the manuscript critically; JBV participated in the coordination of the study, has been involved in drafting the manuscript and revising it critically. 

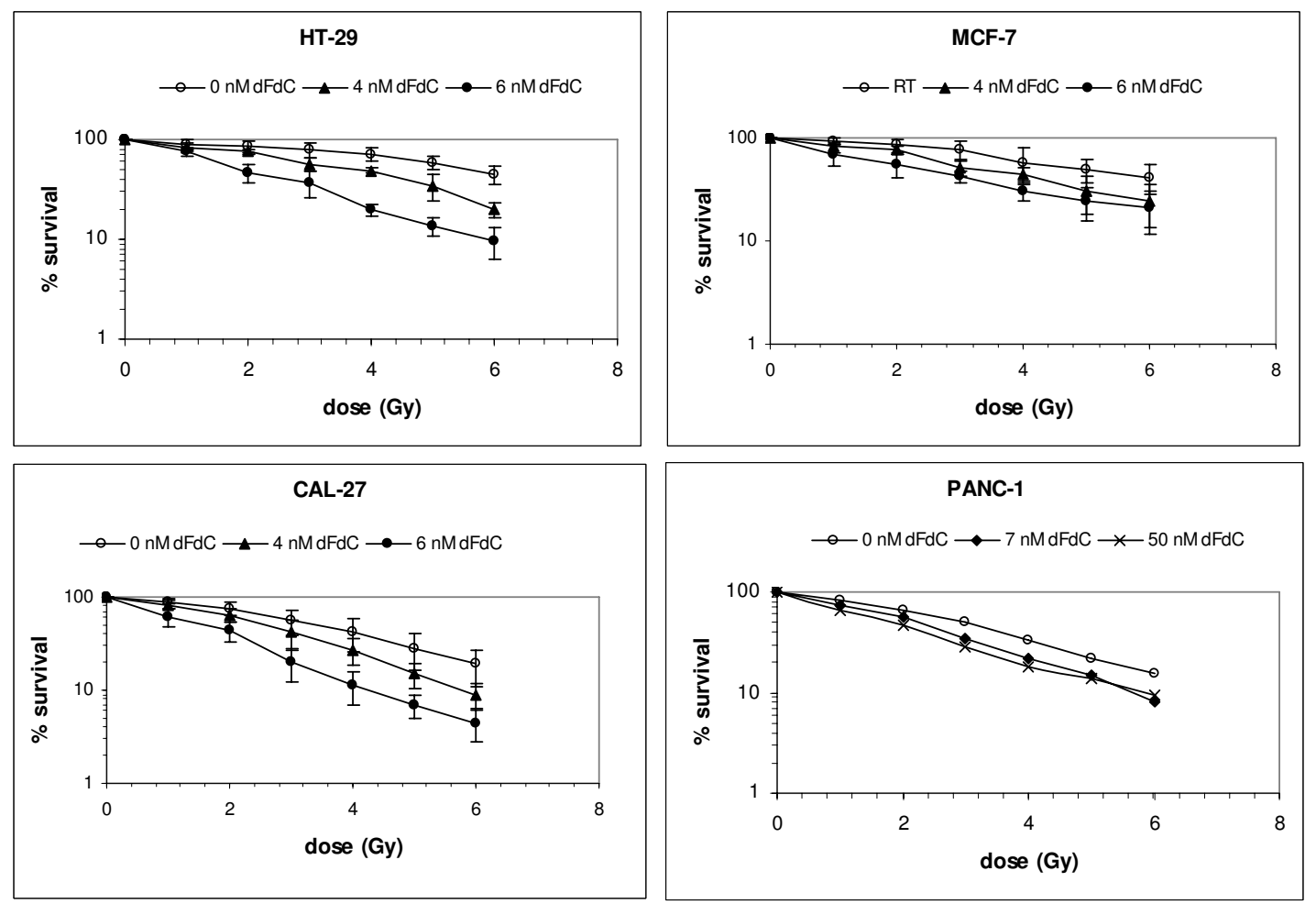

\section{Figure 2}

Radiation dose response curves. Radiation dose responsecurves of HT-29, MCF-7, CAL-27 and Panc-I cells after treatment with gemcitabine $(\mathrm{dFdC})$ during $24 \mathrm{~h}$ immediately before radiation $(\mathrm{RT})$ (survival \pm S.D.)

A

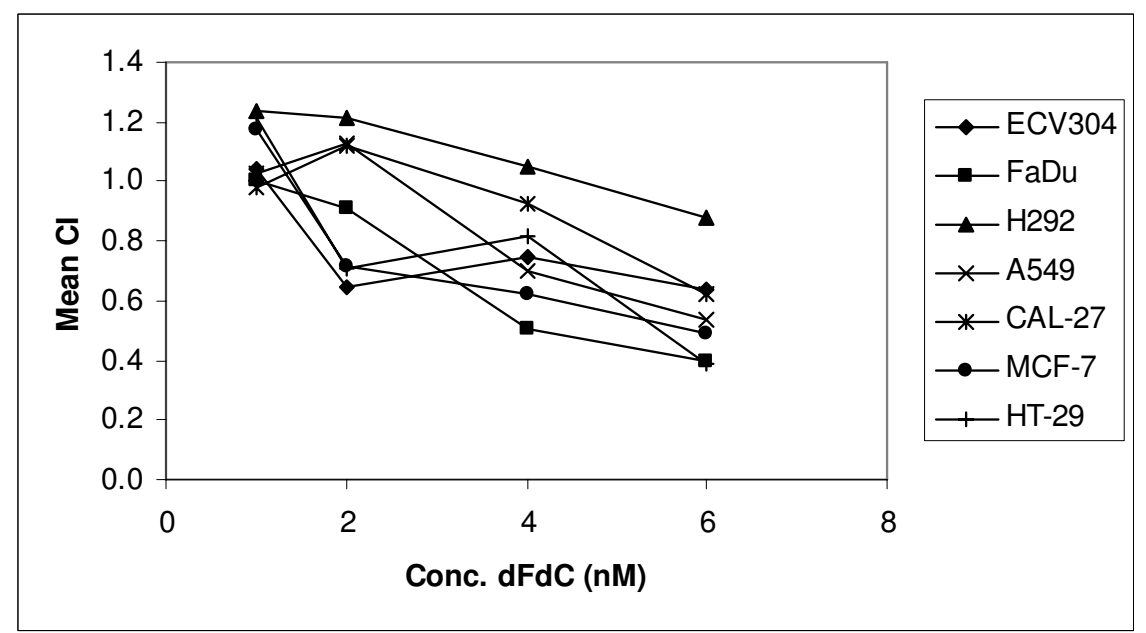

\section{Figure 3}

Relationship between gemcitabine concentration and the combination index. Relationship between the concentration of gemcitabine $(\mathrm{dFdC})$ and the mean combination index $(\mathrm{Cl})$ for ECV304, FaDu, H292, A549, CAL-27, MCF-7 and HT-29 cells. The cells were treated during $24 \mathrm{~h}$ with gemcitabine immediately before radiotherapy $(0-8 \mathrm{~Gy})$. A Cl value between 0.9 and I.I indicates only additivity. Moderate synergism is depicted by $\mathrm{Cl}$ values between 0.7 and 0.9 , synergism by $\mathrm{Cl}$ values below 0.7 . 


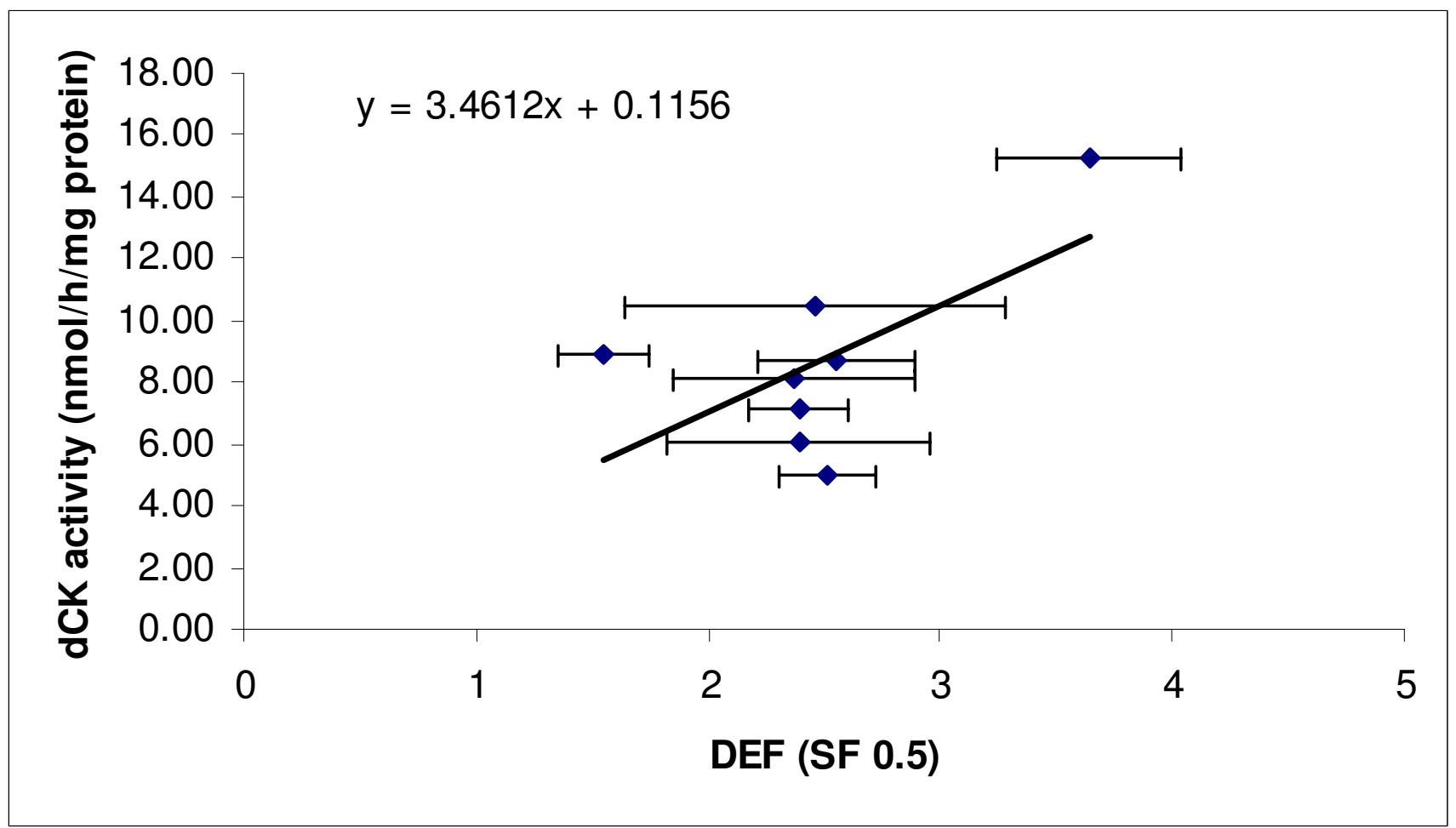

\section{Figure 4}

Relationship between deoxycytidine kinase activity and the radiosensitising effect of gemcitabine. Relationship between deoxycytidine kinase (dCK) activity and the radiosensitising effect of gemcitabine represented by the dose enhancement factor (DEF) for the different human tumour cells. (SF = surviving fraction)

\section{knowledgements}

The authors whish to thank dr. Balz from the University of Düsseldorf for determining the $\mathrm{p} 53$ status of $\mathrm{H} 292$ and CAL-27 cells.

This study was financially supported by a grant from the foundation Emmanuel van der Schueren and by a donation of Mr. Willy Floren.

\section{References}

I. Storniolo AM, Allerheiligen SRB, Pearce H: Preclinical, pharmacologic, and phase I studies of gemcitabine. Semin Oncol 1997, 24(2 Suppl 7):S7-2-S7-7. Review

2. Peters G], Ruiz van Haperen VWT, Bergman AM, Veerman G, Smitskamp-Wilms E, Van Moorsel CJA, Kuiper CM, Braakhuis BJM: Preclinical combination therapy with gemcitabine and mechanisms of resistance. Semin Oncol 1996, 23:16-24.

3. Rockwell S, Grindley GB: Effect of 2'-2'-difluorodeoxycytidine on the viability and radiosensitivity of EMT6 cells in vitro. Oncology Research 1992, 4:I5I-I55.

4. Milas L, Fujii T, Hunter N, Elshaikh M, Mason K, Plunkett W, Ang KK, Hittelman W: Enhancement of tumor radioresponse in vivo by gemcitabine. Cancer Res 1999, 59:107-114.

5. Mason KA, Milas L, Hunter NR, Elshaikh M, Buchmiller L, Kishi K, Hittelman KW, Ang KK: Maximizing therapeutic gain with gemcitabine and fractionated radiation. Int J Radiat Oncol Biol Phys 1999, 44: I I25-I I35.

6. Chen M, Hough AM, Lawrence TS: The role of p53 in gemcitabine-mediated cytotoxicity and radiosensitization. Cancer Chemother Pharmacol 2000, 45:369-374.

7. Latz D, Fleckenstein K, Eble M, Blatter J, Wannenmacher M, Weber $\mathrm{KJ}$ : Radiosensitizing potential of gemcitabine (2',2'-difluoro- 2'-deoxycytidine) within the cell cycle in vitro. Int J Radiat Oncol Biol Phys 1998, 41:875-882.

8. Lawrence TS, Chang EY, Hahn TM, Hertel LW, Shewach S: Radiosensitization of pancreatic cancer cells by 2',2'-difluoro-2'deoxycytidine. Int J Radiat Oncol Biol Phys 1996, 34:867-872.

9. Lawrence TS, Davis MA, Hough A, Rehemtulla A: The role of apoptosis in 2 ',2 '-difluoro-2 '-deoxycytidine (gemcitabine)-mediated radiosensitization. Clin Cancer Res 200।, 7:3।4-319.

10. Mose S, Karapetian M, Juling Pohlit L, Taborski B, Damrau M, Ramm $U$, Rahn A, Bottcher HD: Radiation enhancement of gemcitabinein two human squamous cell carcinoma cell lines. AnticancerRes 2000, 20:40l-405.

II. Ostruszka LJ, Shewach DS: The role of cell cycleprogression in radiosensitization by 2 ',2 '-difluoro-2'-deoxycytidine. Cancer Res 2000, 60:6080-6088.

12. Rosier JF, Beauduin M, Bruniaux M, De Bast M, De Coster B, Octave Prignot $M$, Scalliet $P$, Gregoire $V$ : The effect of 2 '-2 ' difluorodeoxycytidine (dFdC, gemcitabine) on radiation-induced cell lethality in two human head and neck squamous carcinoma cell lines differing in intrinsic radiosensitivity. Int J Radiat Biol 1999, 75:245-25I.

13. Shewach DS, Hahn TM, Chang E, Hertel LW, Lawrence TS: Metabolism of 2',2'-difluoro-2'-deoxycytidine and radiation sensitization of human colon carcinoma cells. Cancer Res 1994, 54:3218-3223.

14. Sangar VK, Cowan R, Margison GP, Hendry JH, Clarke NW: An evaluation of gemcitabines differential radiosensitising effect in related bladder cancer cell lines. Br J Cancer 2004, 90:542-548.

15. Genc M, Kreder NC, Barten van Rijbroek A, Stalpers LJA, Haveman $\mathrm{J}$ : Enhancement of effects of irradiation by gemcitabine in a 
glioblastoma cell line and cell line spheroids. J Cancer Res Clin Oncol 2004, 130:45-5I.

16. Joschko MA, Webster LK, Groves J, Yuen K, Palatsides M, Ball DL, Millward MJ: Enhancement of radiation-induced regrowth delay by gemcitabine in a human tumor xenograft model. Radiat Oncol Invest 1997, 5:62-7I.

17. Eisbruch A, Shewach DS, Bradford CR, Littles JF, Teknos TN, Chepeha DB, Marentette LJ, Terrell JE, Hogikyan ND, Dawson LA, Urba S, Wolf GT, Lawrence TS: Radiation concurrent with gemcitabine for locally advanced head and neck cancer: A phase I trial and intracellular drug incorporation study. J Clin Oncol 200I, 19:792-799.

18. Cetina L, Rivera L, Candelaria M, de la Garza J, Duenas Gonzalez A: Chemoradiation with gemcitabine for cervical cancer in patients with renal failure. Anticancer Drugs 2004, I5:76|-766.

19. Langer CJ: The emerging role of gemcitabine in combination with radiation in locally advanced, unresectable non-smallcell lung cancer. Clin Lung Cancer 2003, 4(suppl 2):S45-9.

20. Lin LL, Picus J, Drebin JA, Linehan DC, Solis J, Strasberg SM, Tan B, Thorstad WL, Myerson R: A phase II study of alternating cycles of split course radiation therapy and gemcitabine chemotherapy for inoperable pancreatic or biliary tract carcinoma. Am J ClinOncol 2005, 28:234-4I.

21. Sangar VK, McBain CA, Lyons J, Ramani VA, Logue JP, Wylie JP, Clarke NW, Cowan RA: Phase I study of conformal radiotherapy with concurrent gemcitabine in locally advanced bladder cancer. Int J Radiat Oncol Biol Phys 2005, 61:420-5.

22. Maraveyas A, Sgouros J, Upadhyay S, Abdel Hamid AH, Holmes M, Lind M: Gemcitabine twice weekly as a radiosensitiser for the treatmentof brain metastases in patients with carcinoma: a phase I study. $\mathrm{Br}$ / Cancer 2005, 92:8I 5-9.

23. Okusaka T, Ito $Y$, Ueno H, Ikeda M, Takezako Y, Morizane $C$, Kagam Y, Ikeda H: Phase II study of radiotherapy combined with gemcitabine for locally advanced pancreatic cancer. $\mathrm{Br}$ / Cancer 2004, $91: 673-677$.

24. Kent E, Sandler H, Montie J, Lee C, Herman J, Esper P, Fardig J, Smith DC: Combined-modality therapy with gemcitabine and radiotherapy as a bladder preservation strategy: Results of a phase I trial. J Clin Oncol 2004, 22:2540-2545

25. Pipas JM, Mitchell SE, Barth RJ, Vera Gimon R, Rathmann J, Meyer LP, Wagman RS, Lewis LD, McDonnell C, Colacchio TA, Perez RP, Amer Brachytherapy Soc: Phase I study of twice-weekly gemcitabine and concomitant external-beam radiotherapy in patients with adenocarcinoma of the pancreas. Int $J$ Radiat Oncol Biol Phys 200I, 50:1317-I322.

26. Ikeda M, Okada S, Tokuuye $\mathrm{K}$, Ueno H, Okusaka T: A phase I trial of weekly gemcitabine and concurrent radiotherapy in patients with locally advanced pancreatic cancer. $\mathrm{Br}$ J Cancer 2002, 86: $155|-| 554$.

27. de Lange SM, van Groeningen CJ, Meijer OWM, Cuesta MA, Langendijk JA, van Riel JMGH, Pinedo HM, Peters GJ, Meijer S, Slotman BJ, Giaccone G: Gemcitabine-radiotherapy in patients with locally advanced pancreatic cancer. Eur J Cancer 2002, 38:1212-1217.

28. Mohiuddin M, Kudrimou M, Regine WF, McGrath PC, Hanna N, John $W$ : Concurrent infusional gemcitabine and radiation in the treatment ofadvanced unresectable GI malignancy: A phase I study. Cancer / 2002, 8:255-262.

29. McGinn CJ, Zalupski MM, Shureiqi I, Robertson JM, Eckhauser FE, Smith DC, Brown D, Hejna G, Strawderman M, Normolle D, Lawrence TS: Phase I trial of radiation dose escalation with concurrent weekly full-dose gemcitabine in patients with advanced pancreatic cancer. J Clin Oncol 200I, 19:4202-4208.

30. Crane $\mathrm{CH}$, Janjan NA, Evans DB, Wolff RA, Ballo MT, Milas L, Mason $\mathrm{K}$, Charnsangavej C, Pisters PWT, Lee JE, Lenzi R, Vauthey JN, Wong A, Phan T, Nguyen Q, Abbruzzese JL: Toxicity and efficacy of concurrent gemcitabine and radiotherapy for locally advanced pancreatic cancer. Int J Pancreatology 200I, 29:9-18.

31. Trodella L, Granone P, Valente S, Turriziani A, Macis G, Corbo GM, Margaritora S, Cesario A, D' Angelillo RM, Gualano G, Ramella S, Galetta D, Cellini N, Italian Cooperative Grp for the St and Cooperative German Austrian Swiss: Phase I trial of weekly gemcitabine and concurrent radiotherapy in patients with inoperable nonsmall-cell lung cancer. J Clin Oncol 2002, 20:804-810.
32. van Putten JWG, Groen HJM, Smid K, Peters G], Kampinga HH: Endjoining deficiency and radiosensitization induced by gemcitabine. Cancer Res 200I, 6 I:I585-I59|.

33. Wachters FM, van Putten JWG, Maring JG, Zdzienicka MZ, Groen $\mathrm{HJM}$, Kampinga HH: Selective targeting of homologous DNA recombination repair by gemcitabine. Int J Rad Oncol Biol Phys 2003, 57:553-562.

34. Robinson BW, Im MM, Ljungman M, Praz F, Shewach DS: Enhanced radiosensitization with gemcitabine in mismatch repair-deficient HCTI I 6 cells. Cancer Res 2003, 63:6935-694I.

35. van Bree C, Rodermond HM, de Vos J, Haveman J, Franken NA: Mismatch repair proficiency is not required for radioenhancement by gemcitabine. Int J Radiat Oncol Biol Phys 2005, 62: I 504-9.

36. Eriksson S, Kierdaszuk B, Munch Petersen B, Oberg B, Johansson NG: Comparison of the substrate specificities of human thymidine kinase $I$ and 2 and deoxycytidine kinase toward antiviral and cytostatic nucleoside analogs. Biochem Biophys Res Commun 1991, 176:586-92.

37. Ruiz van Haperen VW, Veerman G, Eriksson S, Boven E, Stegmann AP, Hermsen M, Vermorken JB, Pinedo HM, Peters G]: Development and molecular characterization of a 2',2'-difluorodeoxycytidine-resistant variant of the human ovarian carcinoma cell line A2780. Cancer Res 1994, 54:4138-43.

38. Bergman AM, Pinedo HM, Jongsma APM, Brouwer M, Ruiz van Haperen VW, Veerman G, Leyva A, Eriksson S, Peters GJ: Decreased resistanceto gemcitabine ( 2 ',2 '-difluorodeoxycitidine) of cytosine arabinoside-resistant myeloblastic murine and rat leukemia cell lines: Role of altered activity and substrate specificity of deoxycytidine kinase. Biochem Pharmacol 1999, 57:397-406

39. Stegmann AP, Honders MW, Hagemeijer A, Hoebee B, Willemze R, Landegent JE: In vitro-induced resistance to the deoxycytidine analogues cytarabine (AraC) and 5-aza-2'-deoxycytidine (DAC) in a rat modelfor acute myeloid leukemia is mediated by mutations in the deoxycytidine kinase (dck) gene. Ann Hematol 1995, 71:41-7.

40. Achiwa H, Oguri T, Sato S, Maeda H, Niimi T, Ueda R: Determinants of sensitivity and resistance to gemcitabine: The roles of human equilibrative nucleoside transporter I and deoxycytidine kinase in non-small cell lung cancer. Cancer Science 2004, 95:753-757.

4I. Kroep JR, Loves WJP, van der Wilt CL, Alvarez E, Talianidis L, Boven E, Braakhuis BJM, van Groeningen C], Pinedo HM, Peters GJ: Pretreatment deoxycytidine kinase levels predict in vivogemcitabine sensitivity. Mol Cancer Ther 2002, I:37I-376.

42. Hapke DM, Stegmann AP, Mitchell BS: Retroviral transferof deoxycytidine kinase into tumor cell lines enhances nucleosidetoxicity. Cancer Res 1996, 56:2343-7.

43. Manome Y, Wen PY, Dong Y, Tanaka T, Mitchell BS, Kufe DW, Fine $\mathrm{HA}$ : Viral vector transduction of the human deoxycytidine kinase cDNA sensitizes glioma cells to the cytotoxic effects of cytosine arabinoside in vitro and in vivo. Nat Med 1996, 2:567-73

44. Stegmann AP, Honders WH, Willemze R, Ruiz van Haperen VW, Landegent JE: Transfection of wild-type deoxycytidine kinase (dck)cDNA into an AraC- and DAC-resistant rat leukemic cell line of clonal origin fully restores drug sensitivity. Blood 1995, 85: I I88-94.

45. van Moorsel CJA, Bergman AM, Veerman G, Voorn DA, Ruiz van Haperen VWT, Kroep JR, Pinedo HM, Peters GJ: Differential effects of gemcitabine on ribonucleotide pools of twenty-one solid tumour and leukaemia cell lines. Biochimica Et Biophysica Acta 2000, I 474:5-I2.

46. van Bree C, Kreder NC, Loves WJP, Franken NAP, Peters G], Haveman J: Sensitivity to ionizing radiation andchemotherapeutic agents in gemcitabine-resistant human tumor cell lines. Int J Radiat Oncol Biol Phys 2002, 54:237-244.

47. Pauwels B, Korst AEC, de Pooter CMJ, Lambrechts HAJ, Pattyn GGO, Lardon F, Vermorken JB: The radiosensitising effect of gemcitabine andthe influence of the rescue agent amifostine in vitro. Eur / Cancer 2003, 39:838-846.

48. Shewach DS, Lawrence TS: Radiosensitization ofhuman tumor cells by gemcitabine in vitro. Semin Oncol 1995, 22:68-7 I.

49. Pauwels B, Korst AEC, de Pooter CMJ, Pattyn GGO, Lambrechts HAJ, Baay MFD, Lardon F, Vermorken JB: Comparison of the sulforhodamine Bassay and the clonogenic assay for in vitro 
chemoradiation studies. Cancer Chemother Pharmacol 2003, $5 \mathrm{I}: 22 \mathrm{I}-226$.

50. Skehan P, Storeng R, Scudiero D, Monks A, McMahon J, Vistica D, Warren JT, Bokesch H, Kenney S, Boyd MR: New colorimetric cytotoxicityassay for anticancer-drug screening. I Natl Cancer Inst 1990, 82: I I07-IIII2.

5I. Papazisis KT, Geromichalos GD, Dimitriadis KA, Kortsaris AH: Optimization of the sulforhodamine B colorimetric assay. J Immunol Methods 1997, 208: I5I-I58.

52. Spasokoukotskaja T, Arner ES, Brosjo O, Gunven P, Juliusson G, Liliemark J, Eriksson S: Expression of deoxycytidine kinase andphosphorylation of 2-chlorodeoxyadenosine in human normal and tumour cells and tissues. Eur J Cancer 1995, 3 I A:202-8.

53. Chou TC, Talalay P: Quantitative analysis of dose-effect relationships: the combined effects of multiple drugs or enzyme inhibitors. Adv Enzyme Regul 1984, 22:27-55.

54. Leonard CE, Chan DC, Chou TC, Kumar R, Bunn PA: Paclitaxel enhances in vitro radiosensitivity of squamous carcinoma cell lines of the head and neck. Cancer Res 1996, 56:5 I98-5204.

55. Chou TC: The median-effect principle and the combination indexfor quantitation of synergism and antagonism. Synergism and Antagonism in Chemotherapy 1991:61-102.

56. Plunkett W, Huang P, Searcy CE, Gandhi V: Gemcitabine: preclinical pharmacology and mechanisms of action. Semin Oncol 1996, 23:3-15

57. van der Wilt CL, Kroep JR, Loves WJP, Rots MG, Van Groeningen CJ, Kaspers G], Peters G]: Expression of deoxycytidine kinase in leukaemic cells compared with solid tumour cell lines, livermetastases and normal liver. Eur J Cancer 2003, 39:69I-697.

58. Gregoire V, Rosier JF, De Bast M, Bruniaux M, De Coster B, Octave Prignot M, Scalliet P: Role of deoxycytidine kinase (dCK) activity in gemcitabine's radioenhancement in mice and human cell lines in vitro. Radiother Oncol 2002, 63:329-338.

59. Robinson BW, Shewach DS: Radiosensitization by gemcitabine in p53 wild-type and mutant MCF-7 breast carcinoma cell lines. Clin Cancer Res 200I, 7:258I-2589.

60. Pauwels B, Korst AEC, Pattyn GGO, Lambrechts HAJ, Van Bockstaele DR, Vermeulen K, Lenjou M, DePooter CMJ, Vermorken JB, Lardon $\mathrm{F}$ : Cell cycle effect of gemcitabine and its role in the radiosensitizing mechanism in vitro. Int J Radiat Oncol Biol Phys 2003, 57:1075-1083.

6I. Mose S, Class R, Weber HW, Rahn A, Brady LW, Bottcher HD: Radiation enhancement by gemcitabine-mediated cell cycle modulations. Am J Clin Oncol 2003, 26:60-69.

62. Hubeek I, Stam RW, Peters GJ, Broekhuizen R, Meijerink JP, van Wering ER, Gibson BE, Creutzig U, Zwaan CM, Cloos J, Kuik DJ, Pieters $R$, Kaspers G]: The human equilibrative nucleoside transporter I mediates in vitro cytarabine sensitivity in childhood acute myeloid leukaemia. Br J Cancer 2005, 93:I388-94.

\section{Pre-publication history}

The pre-publication history for this paper can be accessed here:

http://www.biomedcentral.com/1471-2407/6/142/pre pub

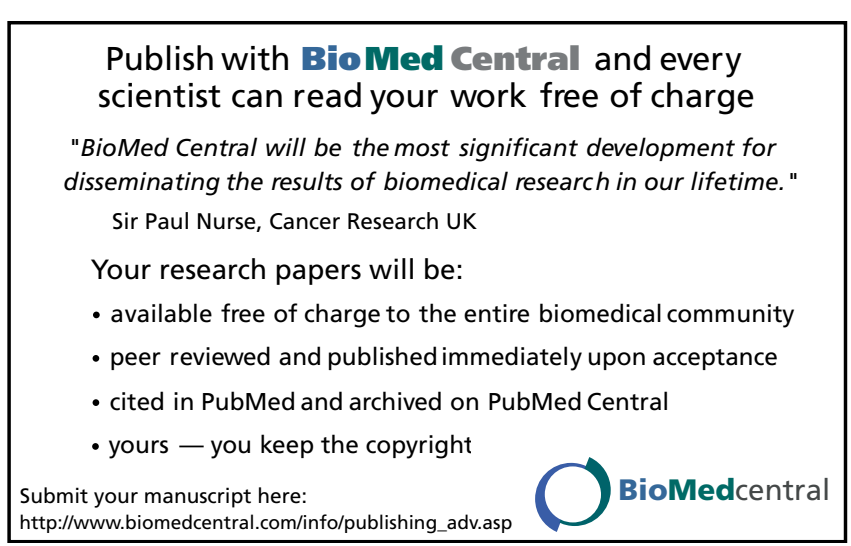

